\title{
KOMPETENSI PEDAGOGIK CALON GURU PROGRAM KEAHLIAN KULINER SMK PARIWISATA
}

\author{
Anggir Nurdianti $^{1}$, Ade Juwaedah ${ }^{1}$, Yulia Rahmawati ${ }^{1}$ \\ Program Studi Pendidikan Tata Boga, Departemen Pendidikan Kesejahteraan \\ Keluarga, Fakultas Teknologi dan Kejuruan, Universitas Pendidikan Indonesia
}

angginurdianti26@gmail.com

\begin{abstract}
Abstrak: Calon guru harus mendekatkan kapasitas kompetensi sebagai guru profesional melalui pembelajaran dan latihan merujuk pada standar kompetensi pedagogik guru sesuai dengan Peraturan Menteri Pendidikan Nasional No. 16 Tahun 2007 tentang standar kualifikasi akademik dan kompetensi guru. Studi pendahuluan di tempat praktik (PPL) menunjukan masih ada calon guru yang belum menguasai kompetensi pedagogik. Melalui penelitian ini, penulis melakukan penelitian dibidang pemahaman kompetensi pedagogik calon guru program keahlian kuliner SMK Pariwisata. Penelitian ini menggambarkan tentang keadaan dari responden yaitu mahasiswa pendidikan tata boga angkatan 2015 sebagai populasi dengan sampel 49 orang. Instrumen yang digunakan adalah tes pilihan ganda yang mencakup; SKL, KI, KD, materi pembelajaran, dan RPP, untuk mendapatkan data sesuai dengan tujuan penelitian. Hasil dari penelitian menunjukan bahwa pemahaman; SKL, KI, dan KD kurikulum SMK 2013, materi pembelajaran program keahlian kuliner kurikulum SMK 2013, dan RPP program keahlian kuliner kurikulum SMK 2013 berada pada kategori cukup baik. Penelitian ini mengandung implikasi bahwa pemahaman responden terkait kompetensi pedagogik pada pengembangan kurikulum perlu ditingkatkan, sehingga akan memudahkan guru praktikan dalam menyelesaikan tugas keguruannya. Rekomendasi untuk penelitian selanjutnya yaitu meneliti secara keseluruhan di delapan aspek kompetensi pedagogik yang belum diteliti oleh penulis.
\end{abstract}

Kata kunci : kompetensi pedagogik, calon guru, SMK Pariwisata

\section{PENDAHULUAN}

Guru merupakan jabatan atau profesi yang memerlukan keahlian khusus sebagai guru (Usman, 2016, hlm 5). Pendidikan yang baik akan menghasilkan sumber daya manusia yang unggul dalam menjawab tantangan di era globalisasi yang penuh kompetensi. Sumber daya manusia dalam suatu LPTK yang dimaksudkan adalah menghasilkan tenaga pendidik atau calon guru profesional dalam dunia pendidikan. Sebagaimana ditegaskan dalam Undang-Undang Nomor 14 Tahun 2005 Pasal 10, menyatakan bahwa "Kompetensi guru sebagaimana dimaksud meliputi kompetensi pedagogik, kompetensi kepribadian, kompetensi sosial, dan kompetensi profesional yang diperoleh melalui pendidikan profesi."

Bidang pendidikan, khususnya yang diperuntukkan bagi calon guru adalah Kompetensi pedagogik yakni keterampilan atau kemampuan dasar yang harus dikuasai oleh seorang calon guru (Choir, 2017, hlm 1). Kompetensi pedagogik adalah kemampuan guru dalam pengelolaan pembelajaran. Menurut Peraturan Menteri Pendidikan Nasional Republik Indonesia Nomor 16 Tahun 2007 Tentang Standar Kualifikasi Akademik dan Kompetensi Guru, kompetensi pedagogik meliputi: (1) menguasai karakteristik peserta didik, (2) menguasai landasan kependidikan, (3) mengembangkan kurikulum, (4) menyelenggarakan pembelajaran yang 
mendidik, (5) memanfaatkan teknologi informasi dan komunikasi, (6) berkomunikasi secara efektif, (7) menyelengarakan penilaian dan evaluasi, (8) memanfaatkan hasil penilaian dan evaluasi proses belajar, dan (9) melakukan tindakan reflektif.

Hasil penelitian yang dilakukan oleh Lilik Chaerul, dkk (2013, hlm 176) menemukan bahwa profil kompetensi guru SMK TKR di Kabupaten Sleman masih kurang baik. Kemampuan dalam menyiapkan RPP dan pelaksanaan pembelajaran masih di bawah rata-rata. Kompetensi profesional, kompetensi kepribadian, kompetensi pedagogik dan kompetensi sosial masih di bawah rata-rata.

Eriawati (2017, hlm 106) dalam penelitiannya menemukan kesulitan yang dihadapi Mahasiswa Program Studi Pendidian Biologi FTK UIN ArRaniry Banda Aceh menguasai materi pelajaran, menentukan metode dan alat/media pembelajaran yang sesuai terhadap materi yang akan diajarkan, melengkapi istrumen atau alat evaluasi pembelajaran.

Berdasarkan penelitian terdahulu yang telah dijelaskan diatas, penulis melihat bahwa kemampuan calon guru dalam menyusun rencana pelaksanaan pembelajara (RPP), menguasai materi pembelajaran, menentukan metode dan alat/media pembelajaran masih kurang menguasai. Sebagaimana yang dikemukakan oleh Moh Surya (dalam Cece, 1991, hlm 4) pengetahuan guru baik tentang subjek materi, maupun mengenai proses belajar mengajar secara keseluruhan sangat menenukan hasil belajar siswa.

Berdasarkan uraian latar belakang, penulis merasa penting untuk mengetahui lebih lanjut tentang "Kompetensi Pedagogik Calon Guru Program Keahlian Kuliner SMK
Pariwisata". Aspek kompetensi meliputi aspek; pengetahuan, keterampilan dan sikap, namun pada penelitian ini akan di batasi yaitu pada aspek pengetahuan tentang konsep dasar kompetensi pedagogik. Terdapat sembilan aspek kompetensi pedagogik guru, maka kompetensi pedagogik dalam konteks penelitian ini yaitu pada aspek pengetahuan pengembangan kurikulum calon guru yang diantaranya adalah pengetahuan menganalisis SKL, KI dan KD, pengetahuan teknik pengembangan materi, dan pengetahuan merancang rencana pelaksanaan pembelajaran

Rumusan masalah penelitian ini yaitu "Bagaimana pengetahuan kompetensi pedagogik calon guru program keahlian kuliner SMK Pariwisata?"

Tujuan dalam penelitian ini adalah untuk memperoleh gambaran mengenai kompetensi pedagogik calon guru program keahlian kuliner SMK Pariwisata, meliputi: (1) Pemahaman Standar Kompetensi Lulusan, Kompetensi Inti, Kompetensi Dasar (SKL, KI, KD) kurikulum SMK 2013 Program Keahlian Kuliner, (2) Pemahaman materi pembelajaran program keahlian kuliner kurikulum SMK 2013 dan (3) Pemahaman Rencana Pelaksanaan Pembelajaran Program Keahlian Kuliner kurikulum SMK 2013.

\section{METODE PENELITIAN}

Metode penelitian yang digunakan adalah metode penelitian deskriptif dengan tujuan untuk mendapatkan gambaran dari suatu keadaan yang ada pada masa sekarang dan sedang berlangsung serta berpusat pada masalah yang aktual (Arikunto, 2013, hlm. 3). Subjek penelitian seluruh mahasiswa Program Studi 
Pendidikan Tata Boga yang akan mengikuti Program Pengalaman Lapangan (PPL) di SMK Pariwisata dengan jumlah populasi 49 orang. Sampel dalam penelitian ini adalah Sensus sehingga mengambil seluruh anggota populasi sebanyak 49 orang menjadi anggota sampel.

Pengumpulan data berupa multiple choice test (pilihan ganda). Sebelum menyebarkan data, penulis melakukan uji validitas instrumen yang dilakukan dengan menggunakan pendapat para ahli (expert judgement). Sebanyak 23 butir soal kemudian disebarkan kepada 45 orang responden melalui aplikasi google docs. Selanjutnya instrumen diperiksa dan diberikan skor, untuk setiap jawaban yang benar diberi skor 1 dan jawaban yang salah diberi skor 0. Jawaban responden kemudian ditabulasi menggunakan bantuan Microsoft Excel 2013. Instrumen yang telah diskor dipersentasekan dan dikategorikan mengadopsi pendapat yang dikemukan oleh Riduwan (2011, hlm.15) mengenai batasan, yang disesuaikan dengan studi pengetahuan yaitu sebagai berikut:

$$
\begin{array}{ll}
81 \%-100 \% & =\text { Sangat baik } \\
61 \%-80 \% & =\text { Baik } \\
41 \%-60 \% & =\text { Cukup baik } \\
21 \%-40 \% & =\text { Buruk } \\
0 \%-20 \% & =\text { Sangat buruk }
\end{array}
$$

\section{HASIL DAN PEMBAHASAN}

Kompetensi pedagogik merupakan salah satu kompetensi dasar yang perlu dikuasai oleh calon guru. Kompetensi pedagogik adalah kemampuan seorang guru mengenai pengelolaan pembelajaran, landasan pendidikan, rencana pelaksanaan pembelajaran (RPP), dan lain-lain. Terdapat 9 indikator dalam kompetensi pedagogik calon guru salah satunya adalah pengembangan kurikulum. Guru dapat menyusun silabus, merancang rencana pelaksanaan pembelajaran yang sesuai dengn silabus, dan mengikuti urutan materi pembelajaran dengan memerhatikan tujuan pembelajaran merupakan aspek pengembangan materi pada kompetensi pedagogik (Husna, 2015, hlm 15).

Data hasil penelitian pengetahuan kompetensi pedagogik berkaitan dengan pemahaman SKL, $\mathrm{KI}$, dan KD program keahlian kuliner kurikulum SMK 2013, presentase menunjukkan bahwa lebih dari setengahnya $(50,94 \%)$ responden menjawab benar dan kurang dari setengahnya $(48,9 \%)$ responden menjawab salah. Instrumen pada indikator ini terkait), pengertian Standar Kompetensi Lulusan (SKL), dimensi pengtahuan taksonomi Bloom, menganalisis kompetensi dasar, langkah menganalisis SKL, KI, dan KD, menganalisis IPK yang berhubungan dengan dimensi pengetahuan, merumuskan IPK berdasarkan kompetensi dasar. Berdasakan data tersebut menunjukkan bahwa pemahaman responden berada pada kriteria cukup baik. Data dapat dilihat pada Gambar 1:

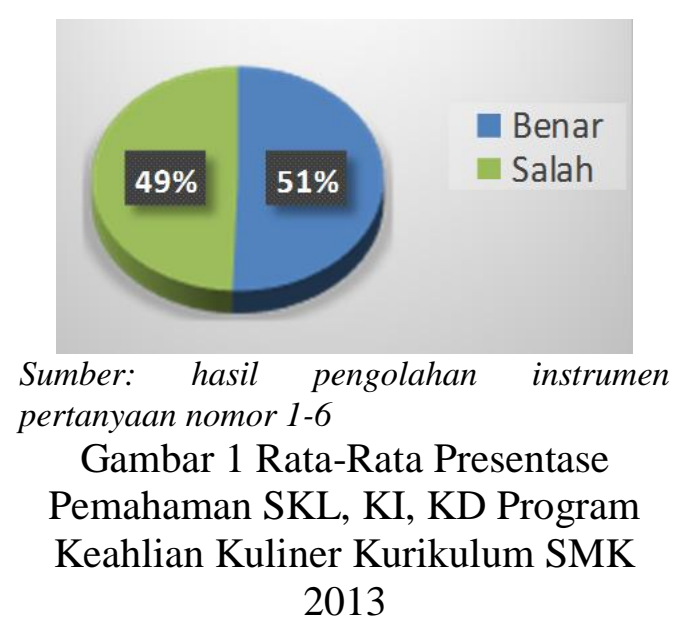


Presentase jawaban benar responden yaitu 50,94\% yang berada pada kriteria cukup baik, sedangkan responden yang menjawab salah yaitu $48,9 \%$. Tingginya presentase jawaban salah dikarenakan responden kurang memerhatikan pernyataan dan pilihan jawabannya sehingga responden secara cepat menjawab tanpa memahami pernyataan dan pilihan jawaban yang telah disediakan oleh penulis.

Kriteria cukup baik menunjukkan bahwa pemahaman responden terkait SKL, KI, dan KD masih harus ditingkatkan lagi untuk menambah wawasan mengenai materi menganalsis SKL, KI,dan KD. Sehingga pada saat pelaksanaan PPL mahasiswa sudah mengetahui, menguasai dan memahami terkait menganalsisi SKL, KI, dan KD pada silabus SMK Kurikulum 2013 dan mengaplikasikannya. Pengetahuan yang dimiliki responden akan berdampak dalam melaksanakan suatu tugas tertentu. Hal ini menunjukkan bahwa pengetahuan yang kurang baik akan memberikan akan berdampak dalam melaksanakan praktik (PPL) yang kurang baik pula.

Pendapat Fuziyah (2014, hlm 27) menyatakan "untuk memenuhi kualifikasi dan kompetensi guru, sebelumnya diperlukan persiapan dan usaha yang relevan". Usaha relevan yang dimaksudkan dapat diartikan sebagai usaha dalam meningkatkan pengetahuan responden terkait menganalisis SKL, KI dan KD sebagai penguasaan kompetensi pedagogik pada aspek pengembangan kurikulum.

Data hasil penelitian pengetahuan kompetensi pedagogik berkaitan dengan pemahaman materi pembelajaran program keahlian kuliner kurikulum SMK 2013, presentase menunjukkan bahwa lebih dari setengahnya $(54,4 \%)$ responden menjawab benar dan kurang dari setengahnya $(45,6 \%)$ responden menjawab salah. Instrumen pada indikator ini terkait pengertian materi pembelajaran, langkah menyusun indikator pencapaian kompetensi, unsur tujuan pembelajara, langkah pengembangan materi pembelajaran, menganalisis kompetensi dasar berdasarkan aspek kognitif, afektif dan psikomotor, menganalisis materi berdasarkan jenis materi pembelajaran, menganalisis materi berdasarkan prinsip pengembangan materi, dan pendekatan dalam mengurutkan materi pembelajaran. Berdasakan data tersebut menunjukkan bahwa responden berada pada kriteria cukup baik. Data dapat dilihat pada Gambar 2:

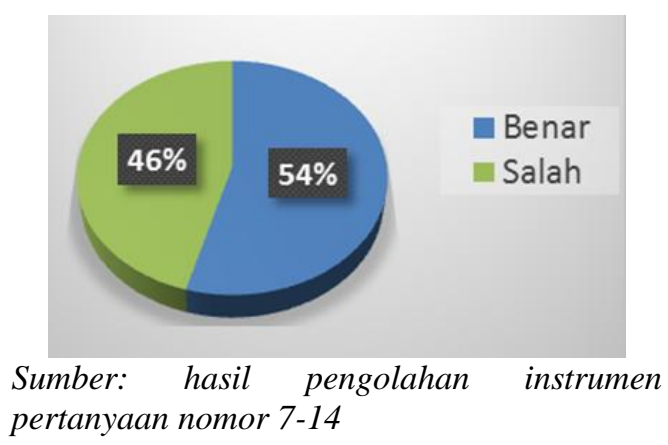

Gambar 2 Rata-Rata Presentase

Pemahaman Materi Pembelajaran Program Keahlian Kuliner Kurikulum SMK 2013

Presentase jawaban benar responden yaitu 54,4\% yang berada pada kriteria cukup baik, sedangkan responden yang menjawab salah yaitu $45,6 \%$. Tingginya presentase jawaban salah dikarenakan sebagian responden tidak mengetahui pilihan jawaban yang benar, sehingga responden cenderung menebak pilihan jawaban yang telah disediakan. 
Kriteria cukup baik menunjukkan bahwa pengetahuan responden terkait materi pembelajaran masih harus ditingkatkan lagi untuk menambah wawasan untuk dapat menerapkan dalam menentukan, memilih dan mengurutkan materi pembelajaran sesuai dengan tujuan pembelajaran dan kebutuhan belajar siswa.

Menurut konsep pengembangan desain pembelajaran (Mulyasa, 2013, hlm 149) "dengan memandang pembelajaran sebagai sistem, isi pembelajaran harus dipilih dan ditentukan sesuai tujuan yang akan dicapai”. Dengan demikian, calon guru harus mempersiapkan materi yang harus diajarkan untuk suatu mata pelajaran yang dapat berubah dari waktu ke waktu sesuai dengan kebutuhan, situasi dan kondisi pembelajaran. Materi pembelajaran harus dipilih dan ditentukan dengan memperhatikan tujuan yang akan dicapai, dengan memperhatikan hal tersebut materi pembelajaran akan tersampaikan dengan baik. Meningkatkan pengetahuan terkait teknik pengembangan materi akan memudahkan calon guru atau mahasiswa praktikan menentukan, memilih dan mengurutkan materi pembelajaran sesuai dengan tujuan pembelajaran dan kebutuhan belajar siswa.

Data hasil penelitian pengetahuan kompetensi pedagogik berkaitan dengan pemahaman rencana pelaksanaan pembelajaran (RPP) Program Keahlian Kuliner Kurikulum SMK 2013, presentase menunjukkan bahwa lebih dari setengahnya $(56,7 \%)$ responden menjawab benar dan kurang dari setengahnya $(43,3 \%)$ responden menjawab salah. Instrumen pada indikator ini terkait pengertian rencana pelaksanaan pembelajaran
(RPP), penyusunan rencana pelaksanaan pembelajaran (RPP), tahapan sistematis dalam meracang rencana pelaksanaan pembelajaran (RPP), komponen rencana pelaksanaan pembelajaran (RPP), syntax model pembelajaran discovery learning, menganalisis kompetensi dasar kedalam metode pembelajaran, kegiatan pembelajaran, menganalisis kompetensi dasar kedalam media pembelajaran, dan menganalisis kompetensi dasar kedalam penilaian pembelajaran. Hal ini menunjukkan bahwa responden berada pada kriteria cukup baik. Dapat dilihat pada Gambar 3:

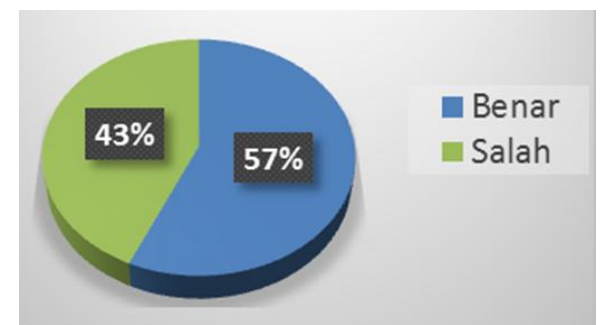

Sumber: Sumber hasil pengolahan instrumen pertanyaan nomor 15-23

Gambar 3. Diagram Rata-Rata

Presentase Pemahaman Rencana

Pelaksanaan Pembelajaran (RPP)

Kurikulum SMK 2013

Presentase jawaban benar responden yaitu lebih dari setengahnya $(56,7 \%)$ yang berada pada kriteria kurang, sedangkan responden yang menjawab salah yaitu kurang dari setengahnya $(43,3 \%)$. Kriteria kurang menunjukkan bahwa pengetahuan responden terkait merancang RPP masih harus ditingkatkan lagi untuk dapat menerapkan dalam merancang dan menyusun rpp serta dapat memilih model, metode, kegiatan pembelajaran, teknik penilaian dan sumber belajar yang tepat digunakan untuk peserta didik yang beragam. 
Menurut Mulyasa (2013, hlm 78) mengatakan "agar proses pembelajaran dapat dilaksanakan secara efisien dan efektif serta mencapai hasil yang diharapkan, diperlukan kegiatan manajemen sistem pembelajaran". Kegiatan manajemen yang dimaksud dapat diartikan sebagai kegiatan merencanakan pembelajaran dalam bentuk perencanaan pembelajaran. Perencanaan dibuat untuk melaksanakan kegiatan pembelajaran secara efektif dan efisien.

Sementara itu Hamzah B. Uno (Andi, 2015, hlm 35) mengungkapkan bahwa perencanaan adalah suatu cara yang memuaskan untuk membuat kegiatan dapat berjalan dengan baik, disertai dengan berbagai langkah yang antisipatif guna memperkecil kesenjangan yang terjadi, sehingga kegiatan tersebut mencapai tujuan yang telah ditetapkan.

\section{SIMPULAN IMPLIKASI DAN REKOMENDASI Simpulan}

Simpulan ini dikemukakan berdasarkan pada tujuan penelitian, pengolahan data dan pembahasan hasil penelitian. Kompetensi pedagogik mahasiswa calon guru program keahlian kuliner meliputi pemahaman SKL, KI dan KD, pemahaman materi, dan pengetahuan merancang rencana pelaksanaan pembelajaran.

Pemahaman SKL, KI, dan KD program keahlian kuliner kurikulum SMK 2013 berada pada kategori cukup baik. Kriteria cukup baik menunjukkan bahwa pemahaman SKL, KI, dan KD masih harus ditingkatkan lagi untuk menambah wawasan mengenai SKL, KI,dan KD. Sehingga dapat mengaplikasikannya pada saat pelaksnaan PPL.

\begin{abstract}
Pemahaman
materi pembelajaran program keahlian kuliner kurikulum SMK 2013 berada pada kategori cukup baik. Kriteria cukup baik menunjukkan bahwa pemahaman mahasiswa praktikan terkait materi pembelajaran masih harus ditingkatkan dengan cara mempelajari dan berlatih terus menerus dalam menyusun IPK, tujuan pembelajan dan materi yang akan digunakan. Sehingga dapat menerapkan dalam menentukan, memilih dan mengurutkan materi pembelajaran sesuai dengan tujuan pembelajaran dan kebutuhan belajar siswa pada saat pelaksanaan PPL.

Pemahaman

rencana pelaksanaan pembelajaran program keahlian kuliner kurikulum 2013 berada pada kategori cukup baik. Kriteria cukup baik menunjukkan bahwa pemahaman responden terkait RPP masih harus ditingkatkan lagi untuk dapat menerapkan dalam merancang dan menyusun rpp serta dapat memilih model, metode, kegiatan pembelajaran, teknik penilaian dan sumber belajar yang tepat digunakan untuk peserta didik yang beragam.
\end{abstract}

\section{Implikasi dan Rekomendasi}

Kompetensi pedagogik aspek pengembangan kurikulum pada mahasiswa Program Studi Pendidikan Tata Boga yang merupakan pengetahuan mutlak yang harus dimiliki oleh seorang calon guru termasuk dalam kategori cukup baik, hal ini mengandung implikasi bahwa mahasiswa harus lebih mematangkan dan terbuka terhadap pengetahuan kompetensi pedagogik khususnya terkait pengembangan kurikulum tentang menganalisis SKL, KI, KD, teknik pengembangan materi, dan 
merancang pelaksanaan pembelajaran secara bersungguh-sungguh agar terbiasa dengan tugas administrasi guru pada saat pelaksanaan PPL.

Rekomendasi penulis tujukan pada: (1) Mahasiswa Pendidikan Tata Boga calon guru praktikan PPL, agar lebih mematangkan pengetahuannya mengenai kompetensi pedagogik khususnya terkait pengembangan kurikulum tentang menganalisis SKL, $\mathrm{KI}$, dan $\mathrm{KD}$, teknik pengembangan materi, dan rancangan pelaksanaan pembelajaran (RPP) dengan bersungguh-sungguh karena akan terasa manfaatnya ketika penyusunan administrasi mengajar pada saat pelaksanaan PPL. (2) Dosen pengampu mata kuliah keahlian profesi, pada saat bahasan mengenai administrasi mengajar guru agar lebih banyak melakukan praktik dalam menganalisis SKL, KI, dan KD, teknik pengembangan materi, dan merancang pelaksanaan pembelajaran. Hal ini agar mahasiswa lebih memahami dan terbiasa dengan tugas administasi guru pada saat pelaksanaan PPL. (3) Peneliti selanjutnya, penelitian mengenai kompetensi pedagogik masih mempunyai delapan aspek yang belum diteliti, sehingga dapat dijadikan rekomendasi penelitian selanjutnya untuk menyempurnakan penelitian sebelumnya yang masih banyak kekurangan.

\section{REFERENSI}

Arikunto, S. (2013). Prosedur Penelitian Suatu Pendekatan Praktik. Jakarta: PT. Rhineka Cipta

Asmara, Husna. (2016). Profesi Kependidikan. Bandung: ALFABETA
Chaerul, Lilik dkk. (2013). Profil Kompetensi Guru Sekolah Menengah Kejuruan Teknik Otomotif Di Kabupaten Sleman. Jurnal Pendidikan Teknologi dan Kejuruan, 176.

Choir, Afidatul, I. (2017). Profil Kompetensi Pedagogik Calon Guru Pendidikan Matematika UN PGRI Kediri. Artikel Skripsi Universitas Nusantara PGRI Kediri, 1.

Eriawati. (2017). Kompetensi Pedagogik Mahasiswa Program Studi Pendidikan Biologi FTK UIN Ar-Raniry. Conference Proceedings - ARICIS I, 106.

Fauziah, I. (2015). Analisis Kesiapan Mahasiswa Program Studi Pendidikan Bahasa Perancis Universitas Negeri Semarang dalam Melaksanakan Praktik Pengalaman Lapangan (PPL) Tahun 2014. (Skripsi). Semarang : Universitas Negeri Semarang

Mada, S. U. (t.thn.). UU Guru dan Dosen. Dipetik 01 30, 2018, dari http://luk.staff.ugm.ac.id/atur/U U14-2005GuruDosen.pdf

Mulyasa, E. (2013). Standar Kompetensi dan Sertifikasi Guru. Bandung: PT Remaja Rosdakarya.

Peraturan Menteri Pendidikan Nasional No 16 Tahun 2007 Tentang Standar Kualifikasi Akademik dan Kompetensi Guru.

Riduwan. (2011). Skala Pengukuran Variabel-variabel Penelitian. Bandung: Alfabeta

Sugiyono, P. D. (2017). Metode Penelitian Kuantitatif, Kualitatif, dan R\&D. Bandung: ALFABETA. 
Undang-Undang Republik Indonesia No. 20 Tahun 2003 Tentang Sistem Pendidikan Nasional

Usman, Moh. Uzer. 2016. Menjadi Guru Profesional. Bandung: Remaja Rosdakarya.
Wijaya, Cece. (1991). Kemampuaan guru dalam proses belajar mengajar. Bandung: PT Remaja Rosdakarya. 